\title{
Guidance And Counseling Services For Women Victims Of Domestic Violence
}

\author{
Afdal Afdala ${ }^{\text {, Alizamar Alizamara }}$, Ifdil Ifdila, Erlamsyah Erlamsyah ${ }^{a}$, Taufik Taufik $^{\mathrm{a}}$ \\ ${ }^{a}$ Department Guidance and Counseling, Faculty of Education, Universitas Negeri Padang, Street of Prof. Dr. Hamka \\ Air Tawar Padang, West Sumatera, Indonesia \\ Corresponding e-mail: afdal@konselor.org
}

\begin{abstract}
Domestic Violence (DV) is defined as every act against a person, especially a woman, resulting in physical, sexual, psychological, or neglectful misery or suffering. In addition to alleviating problems through legal channels, other things that can be done is through guidance and counseling services. This research is a preliminary research in order to find the model of settlement of cases of domestic violence. The research method used is quantitative. The sample in this study was 63 women victims of violence. Data were collected through Indonesian Domestic Violence for Woman questionnaire. Data were analyzed descriptively to obtain a description of domestic violence experienced by women. Further data are analyzed with independent sample t test to see the difference of violence which is natural for woman based on marriage age. The results of the study showed that (1) the most frequent violence experienced by women was psychic violence, (2) there was a significant difference in violence experienced by women victims of domestic violence where the average of violence experienced by women with low marriage age (under 10 years) High compared with higher marriage age (above 10 years). Further discussed counseling and guidance services to help women victims of domestic violence.
\end{abstract}

Keywords: Domestic Violence, guidance and counseling services

\section{INTRODUCTION}

The problem of domestic violence (DV) becomes one of the issues that become the current hot talk, given the domestic violence often occurs and result in losses that not only emotionally losses but also have an impact on the psychological functioning of the patient. Trevillion, Oram, Feder, \& Howard (2012) explain that domestic violence is an international public health problem affecting the lives of hundreds of thousands of people every year [1]. Globally, the prevalence estimates of physical and sexual violence in women range from $15 \%$ $71 \%$ with estimates last year ranging from $4 \%$ and $54 \%$. Data in Indonesia indicate that domestic violence (especially for women / wives) is reported to increase, $72 \%$ among reported cases conducted by husband, the rest is done by ex husband, boyfriend, relatives or parents and $4.5 \%$ from Women reporting are under 18 years of age [2] - [4].

For that reason, the Indonesian government has set a legal basis for the elimination of domestic violence (DV) through Law no. 23. However, although the law already exists and the legal consequences are clear, domestic violence is still a frightening specter and a problem that must be resolved soon [3] - [5].

The United Nations Declaration on the Elimination of Violence (1993) defines violence as any act of violence that results in, or tends to result in physical, sexual or psychological harassment, including threats of action, coercion or arbitrary behavior to the deprivation of liberty which may occur In public or in the condition of a [3]. From some of the above understanding it is clear that domestic violence occurs mostly in women and children but is also likely to occur in male subjects [3].

Law no. 23 of 2004 article 5 divides the types of domestic violence into four types: physical violence, psychic violence, sexual violence and neglect of households [4]. In a variety of literatures, neglect is also classified as economic violence which can include denial of funds, refusal to contribute financially, denial of food and basic necessities, and control access to health care, employment, etc. [3].

As with many types of domestic violence, the factors that cause domestic violence are also diverse. Domestic violence is caused by several factors, namely cultural, economic, legal / legal / legal, and 
political factors [2] - [9]. Furthermore, Djannah (2002) and Irma Syahfitri (2007) suggest that domestic violence is caused by economic factors, third-party presence, misconception, wrong role models, and psychological conditions [10] - [11].

Meanwhile, Azis (2002) suggests the causes of violence against women, namely: (a) patriarchal culture which dominates men as superior creatures and women as interior creatures, (b) a misconception of religious teachings that assume men May rule over women and (c) imitation of a boy living with a hitting father, will usually imitate his father's behavior [12].

\section{METHODOLOGY}

This study aims to generate a description of the number of cases of domestic violence reported in West Sumatera and the forms of violence experienced by women victims of domestic violence. This research is quantitative descriptive research. Data concerning the number of cases of domestic violence were collected from the number of cases reported /handled by the West Sumatera Regional Police Sub Directorate of Women and Children Protection in 2013-2015. While data concerning the form of domestic violence experienced by women were collected against 30 women victims of domestic violence obtained from Center for Integrated Service of Empowerment of Children and Children (Pusat Pelayanan Terpadu Pemberdayaan Perempua dan Anak--P2TP2A) in West Sumatera. Data regarding the form of domestic violence experienced by women were collected by a Likert scale model questionnaire. Further data is processed descriptively and tested the difference based on age of marriage.

\section{RESULTS AND DISCUSSION}

Research on domestic violence can be elaborated into 2 main outcomes, namely the description of the number of domestic violence cases in West Sumatera and the forms of domestic violence experienced by women victims of violence. The results are presented in the following explanation:

Description of the number of cases of domestic violence in West Sumatera

Research on the number of cases of domestic violence in recent years has increased significantly. This can be seen from the table as:
Table 1. DV Cases Number of Reported in West Sumatera

\begin{tabular}{|c|c|c|c|c|c|}
\hline \multirow[b]{2}{*}{ No } & \multirow[b]{2}{*}{ Regency/City } & \multicolumn{4}{|c|}{ Number of reported } \\
\hline & & 2013 & 2014 & 2015 & $\begin{array}{l}\text { Agus } \\
2016\end{array}$ \\
\hline 1 & Padang & 108 & 115 & 112 & 81 \\
\hline 2 & $\begin{array}{l}\text { Bukittinggi/Aga } \\
\mathrm{m}\end{array}$ & 34 & 40 & 22 & 14 \\
\hline 3 & Limapuluhkota & 14 & 17 & 7 & 9 \\
\hline 4 & Tanah Datar & 7 & 5 & 6 & 8 \\
\hline & Total & 163 & 167 & 147 & 112 \\
\hline
\end{tabular}

Source: West Sumatera Regional Police, Agustus 2016

Table 1. shows the results of an increase in reported cases of domestic violence in various cities in West Sumatera, with details of (1) Padang, which in 2013 had a DV case of 108 cases having increased by $6.4 \%$ to 115 cases in 2014, (2) Bukittinggi/Agam, which in 2013 has a DV case of 34 cases increased by $17.64 \%$ to 40 cases in 2014 , (3) Limapuluhkota, which in 2013 has a DV case of 14 cases Experienced an increase of $21.42 \%$ to 17 cases in 2014, (4) Tanahdatar, which in 2013 had a DV case of 7 cases increased by $14.28 \%$ to 8 cases in 2014. Overall cases of violence in households in some districts / The city in West Sumatera has increased the case by $10.42 \%$ to 180 cases in 2014 . While in the medium year 2016, some district/city of West Sumatera already has a DV case of 112 cases, which, when viewed from per month in West Sumatera on average have cases of domestic violence as many as 14 cases/month.

Furthermore, the reported distribution of victims of violence can be seen in Table 2 following:

Table 2. Distribution of DV Victims Reported in West Sumatera at 2015-2016

\begin{tabular}{|c|c|c|c|c|c|}
\hline \multirow[b]{2}{*}{ No } & \multirow[b]{2}{*}{ Regency/City } & \multicolumn{4}{|c|}{ Victims of Violence } \\
\hline & & $\begin{array}{l}\text { Women/ } \\
\text { Wife }\end{array}$ & Child & Husband & Other \\
\hline 1. & Padang & 39 & 74 & - & 31 \\
\hline 2 & Bukittinggi/Agam & 69 & - & 1 & - \\
\hline 3. & Limapuluhkota & 14 & 3 & 1 & - \\
\hline 4. & Tanah Datar & 18 & 6 & - & 3 \\
\hline & Total & 140 & 83 & 2 & 34 \\
\hline & $\begin{array}{l}\text { Percentage of All } \\
\text { Cases ( } 259 \text { cases) }\end{array}$ & 54.05 & 32.05 & 0.77 & 13.13 \\
\hline
\end{tabular}

Source: West Sumatera Regional Police

Table 2 overall shows that DV victims are most commonly experienced by Women/Wives with a percentage of $54.05 \%$. With details of Padang as many as 39 cases, Bukittinggi/Agam as many as 69 cases, Limapuluhkota as many as 14 cases and 
Tanah Datar as many as 18 cases. Table 5.2. Also gave information that, besides woman / wife, child become second victim of violence with percentage equal to $32.05 \%$ (83 cases), with detail of Padang city counted 74 cases, Limapuluhkota regency 3 cases and Tanah Datar regency 6 cases.

Description of the type of domestic violence experienced by women

Violence experienced by women is described in the table as follows:

Table 3. The type of violence experienced by the victim woman

\begin{tabular}{|c|l|c|c|r|r|c|}
\hline \multirow{2}{*}{$\mathrm{N}$} & & PhyV & PsyV & SV & NV & DV \\
\cline { 2 - 8 } & Valid & 63 & 63 & 63 & 63 & 63 \\
\cline { 2 - 8 } & Missing & 0 & 0 & 0 & 0 & 0 \\
\hline \multicolumn{2}{|c|}{ Mean } & 26.52 & 63.44 & 35.93 & 41.88 & 167.83 \\
\hline \multicolumn{2}{|c|}{ Median } & 27.00 & 64.00 & 37.00 & 42.00 & 163 \\
\hline \multicolumn{2}{|c|}{ Mode } & 33.00 & 56.00 & 29.00 & 42.00 & 163 \\
\hline \multicolumn{2}{|c|}{ Std. Deviation } & 6.90 & 9.37 & 9.45 & 9.80 & 26.24 \\
\hline
\end{tabular}

PhyV : Physical violence

PsyV : Psychological violence

SV : Sexual violence

NV : Neglect violence

DV : Domestic violence

Table 3 shows that overall violence experienced by DV victim women was in the moderate category with an average of 167.83 . The data also illustrate the average of violence seen from several aspects, namely physical violence, psychic violence, sexual violence and economic neglect. The data per indicator shows that the most abusive violence is psychic violence, with an average of 63.44 , followed by violence in the form of neglect / giving economic needs (41.88), sexual violence (35.96), and physical violence (26.52).

Table 3 shows that most women victims of violence are more likely to experience psychic violence in the household. This is according to Adjah \& Agbemafle (2016) study which shows that psychic violence is the reported violence as the most common form of domestic violence against women [13]. Psychic violence occurs by degrading the image of wives through words, forbidding wives to associate with others and separating wives associating with children and their families [8] - [9], [13] - [14]. [21]. Some domestic violence in the case of psychic violence can occur because of the interference of third parties, such as cases of infidelity, which ultimately leads to ineffective communication [7], [13], [21].
Further research results also illustrate the violence experienced by women victims of domestic violence, described in table 4 below:

Table 4. Differences in Woman Victim Violence by Age of Marriage

\begin{tabular}{|l|l|c|c|c|c|c|}
\hline \multirow{2}{*}{} & $\begin{array}{l}\text { Age of } \\
\text { Marriage }\end{array}$ & $\mathrm{N}$ & Mean & $\begin{array}{l}\% \text { mean } \\
\text { from } \\
\text { max. }\end{array}$ & $\begin{array}{c}\text { Std. } \\
\text { Deviation }\end{array}$ & $\begin{array}{l}\mathrm{t} \\
\text { Sig. }\end{array}$ \\
\hline \multirow{2}{*}{ PhyV } & UNDER10 & 35 & 28.80 & 57.60 & 6.27 & 3.12 \\
\cline { 2 - 7 } & UP10 & 28 & 23.67 & 47.34 & 6.70 & .003 \\
\hline \multirow{2}{*}{ PsyV } & UNDER10 & 35 & 68.34 & 65.69 & 7.99 & 5.69 \\
\cline { 2 - 8 } & UP10 & 28 & 57.32 & 54.59 & 7.15 & .000 \\
\hline \multirow{2}{*}{ SV } & UNDER10 & 35 & 40.22 & 61.88 & 8.71 & 4.60 \\
\cline { 2 - 8 } & UP10 & 28 & 30.64 & 47.14 & 7.54 & .000 \\
\hline \multirow{2}{*}{ NV } & UNDER10 & 35 & 45.97 & 65.67 & 9.40 & 4.01 \\
\cline { 2 - 7 } & UP10 & 28 & 36.96 & 52.80 & 8.16 & .000 \\
\hline \multirow{2}{*}{ DV } & UNDER10 & 35 & 183.34 & 63.22 & 20.26 & 6.98 \\
\cline { 2 - 7 } & UP10 & 28 & 148.43 & 51.18 & 19.03 & .000 \\
\hline
\end{tabular}

Table 4 explains that there is a significant difference in violence experienced by women victims of domestic violence with a value of $t$ test of 6.97 , significance of 0.00 . It further explained that the lower the age of female marriage, the more likely it is to experience domestic violence with a mean difference of 183.34 for marriages under 10 years and 148.43 for marriage over 10 years. Differences in violence experienced by women under the age of marriage under 10 years are also higher in comparison with women with age of marriage above 10 years either on physical violence, psychic violence, sexual violence or violence in the form of economic neglect. The results of this study are in line with Lewis and Spanier research which states that the younger the marriage age of a person, the higher the temptation that will disrupt the sustainability of the family, which can trigger domestic violence and create problems in the household such as defiance of the rules, Lack of understanding with respect to duties and rights as wives, and other factors [5], [15] - [16].

The difference analysis in Table 4 describes that the highest average percentage of experienced by women victims of violence is violence in the form of psychic violence, which is then followed by neglect, sexual violence and physical violence. This is of interest to researchers considering that violence is more likely to be known by physical behavior (injuring / torturing with limbs or objects), currently defeated by psychic violence (degrading the image of wives through words, forbidding wives to associate with others, separating wives from Children and their families) sexual (in the form of 
isolating the wife from his inner needs, coercion with his wife, etc.) and even neglect (not providing for his wife, utilizing his wife's economic dependency to control the wife's life, allowing her to work for later Husband) [3]. The trends of violence experienced by women from the outset of physical violence to psychic, sexual violence and economic neglect may be due to the fear of the perpetrators of the punishment they will get, since physical violence provides tangible evidence for victimization as a strong proof of the police and courts.

Increased cases of domestic violence further indicate the need for counseling and counseling services by counselors in Indonesia. In various rules, explicitly the role of counselors in Indonesia is not explained clearly and in detail with respect to cases of domestic violence. However, as an overall profession the counselor has a great role and responsibility in solving cases of domestic violence psychologically. This illustrates that counselors at school are ready, out of school steady and everywhere spry [20].

The role of counselors is possible in cases of violence because counselors are the individuals who best understand and understand the client's development and how to do it in helping the client achieve a more effective daily living (EDL) [20]. In this regard, the competencies expected in the counselor to assist in the eradication of DV problems can be formulated into the competence of knowledge, skills and abilities and attitude competencies [3], [16]-[19]. With regard to the competence of knowledge, the counselor is expected to understand the condition of his clients thoroughly, be it with regard to physical conditions and psychological conditions that will affect the behavior/relationship clients. The counselor should be able to understand the knowledge pertaining to the theories and techniques related to the business of helping the client and his family optimize themselves with regard to the problem. The counselor should have a clear understanding of the cultural, political and social conditions that affect the client's development and understand that collaborating with various parties (in other family members) has an important role in achieving the goal of guidance and counseling services [3].

In addition to having competence with regard to the condition of clients and dimensions of life, counselors are expected to have the skills to use and develop various techniques and strategies that can be done in helping clients to alleviate the problem. In the case of violence, counselors should be able to use various alternative techniques and approaches that are assumed to have significant effectiveness in solving and resolving cases of domestic violence. The alternative techniques and strategies used by counselors can be applied individually (both to victims and perpetrators) or to groups (in larger families). Other competencies that must be performed and performed by the counselor are competencies related to the accountability of the assistance program such as the reporting of the activity or the guidance program, the evaluation of the implementation of the program and the followup that will be done with regard to the implementation of the program already done. The ability to report on guidance activities or programs becomes important in the counselor so that guidance and counseling programs can be held accountable [3].

The competencies that the counselor must possess in addition to the competence of knowledge, skills and skills are competencies with attitudes. The attitude that is meant here is a positive attitude towards and others [3], [16] - [17]. A positive attitude toward oneself will provide awareness, the desire to do better, the desire to help others because he considers himself to have the ability and responsibility of the profession, and various other attitudes that will affect himself and his consciousness. A positive attitude is also needed against the person outside of the counselor who will influence the implementation of counseling and guidance.

This study only discusses descriptively images of violence experienced by women victims of violence. For that, further research needs to be studied more deeply due to the violence experienced by women victims of domestic violence against their lives through interviews, observation and other data collection. Furthermore, research needs to be done with regard to the use of counseling models/techniques in assisting psychologically women victims of violence.

\section{CONCLUSION}

The results of this study indicate that (1) there is an increase in the number of domestic violence cases reported to the police in West Sumatera, (2) the trend of violence experienced by women victims of violence has changed from physical violence to psychic violence, violence in the form of neglect and Sexual violence. As evidenced by the high achievement of psychic violence, neglect and sexual abuse versus physical violence, (3) there is a significant difference in violence experienced by women victims by age of marriage, where women victims of lower marriage age tend to experience higher violence than With women victims who have a higher marriage age. For that (1) counselor / counselor candidate, it is necessary to have various competence, be it knowledge competence, abilities 
and skills competence and attitude competence to assist client with violence case or also perpetrator of violence; (2) government, there needs to be a more comprehensive legal protection effort for victims of violence, which can identify violence, not only physical violence, but also psychic violence, neglect and sexual violence; (3) prospective wife / husband, need to be equipped with knowledge regarding the ideal family, without violence.

\section{REFERENCES}

Trevillion, K., Oram, S., Feder, G., \& Howard, L. M. (2012). "Experiences of Domestic Violence and Mental Disorders: A Systematic Review and Meta-Analysis". Journal. December 2012| volume 7| issue 12| e51740.

Komnas Perempuan. (2001). Peta Kekerasan Pengalaman Perempuan Indonesia. Jakarta: Ameepro.

[1] Afdal, A. (2015). Pemanfaatan Konseling Keluarga Eksperensial untuk Penyelesaian Kasus Kekerasan dalam Rumah Tangga. Jurnal EDUCATIO: Jurnal Pendidikan Indonesia, 1(1).

[2] Undang-Undang Republik Indonesia Nomor 23. (2004). Penghapusan Kekerasan dalam Rumah Tangga.

[3] Ribka, P. D. (1998). Tindak kekerasan terhadap perempuan dalam keluarga (Doctoral dissertation, Pasca Sarjana-UI).

[4] Cowie, H., \& Jennifer, D. (2009). Penanganan Kekerasan di Sekolah (penerjemah: Ursula Gyani). Jakarta: PT Indeks.

[5] Moerti, H. S. (2012). Kekerasan dalam Rumah Tangga. Jakarta: Sinar Grafika.

[6] Annunziata, P. SS. (2000). "Domestic Violance". UNICEF Innocenti Research Centre. 50122 Florence, Italy No. 6-June 2000.

[7] Unicef. (2000). and Innocenti Research Center. 2000. Domestic Violence against Women and Girls. Innocenti Digest, (6).

[8] Djannah, F. (2003). Kekerasan terhadap istri. PT LKiS Pelangi Aksara.

[9] Syahfitri, I. (2007). Upaya polri Dalam Mengungkap Kekerasan dalam Rumah Tangga/KDRT: Studi di Polres Lamongan. Skripsi. FH Universitas Brawijaya Malang.

[10] Afdal, Alizamar, \& Ifdil. (2016). Peran Konselor dalam Penyelesaian Kasus Kekerasan dalam Rumah Tangga. Makalah. Disampaikan pada Konvensi Nasional ABKIN tanggal 20-21 Mei 2016.
[11] Adjah, E. S. O., \& Agbemafle, I. (2016). Determinants of domestic violence against women in Ghana. BMC public health, 16(1), 368.

[12] Matthews, B. (2015). Dawn of Australian domestic violence. Eureka Street, 25(24), 46.

[13] Sumayku, G. P., Tomuka, D., \& Kristanto, E. (2016). Hubungan usia waktu menikah dengan kejadian kekerasan pada anak di Kota Manado Bulan Oktober 2014-Oktober 2016. e-CliniC, 4(2).

[14] Sukardi, D. (2015). Kajian kekerasan rumah tangga dalam perspektif hukum islam dan hukum positif. Mahkamah: Jurnal Kajian Hukum Islam, 9(1).

[15] Brian, M. (2015). "Dawn of Australian Domestic Violance”. Journal. Eureka Street vol 25 no 24 06-Des-2015.

[16] Brown, J., \& James, K. (2014). "Therapeutic Responses to Domestic Violence In Australia: A History of Controversies". Australian and New Zealand Journal of family therapy 2014, 35, 169-184 doi: 10.1002/anzf.1053.

[17] Doku, D. T., \& Asante, K. O. (2015). "Women's approval of domestic physical violance against wives analysis of the ghana demographic and health survey". Doku and Asante BMC Women's Health. DOI 10.1186/S12905-015-0276-0.

[18] Prayitno, dkk. (2015). Pembelajaran melalui pelayanan $B K$ di Satuan Pendidikan. Yogyakarta: Pramitra Publishing

[19] Facrina \& Anggraini, N. (2007). Kekerasan terhadap Perempuan dalam Keluarga pada Masyarakat Minangkabau Kontemporer. FISIP. UNAND. 